\title{
Social Organization of Work and Labour Conflicts in Proto-Industrial Iron Production in Sweden, Belgium and Russia
}

\section{ANDERS FLORÉN}

There exists no such thing as a single mode for the social organization of proto-industrial iron production, but a number of alternative ways. In the following article the dominance of one or another mode is viewed as dependent on its societal context, and not least on the social relations of the rural world. Each mode of organization had its own peculiarities and generated its own contradictions and conflicts.

To be able to deal with the subject, a comparative approach has been chosen, and three different regions have been studied, namely Bergslagen in central Sweden, Walloonia in today's Belgium and the Urals in Russia. ${ }^{1}$ All three of them have, during different periods, been central for the European production of iron from the sixteenth to the nineteenth century. Economically and politically they all embodied different types of society. Feudal and Tsarist Russia was characterized by its reinforcement of serfdom parallel to its attempts to westernize; representative of Sweden was its small and weak towns and traditionally free peasant class. The politically weak and scattered Walloon lands were divided principally between the House of Habsburg and the independent bishopric of Liège, and constituted a region with considerable economic as well as social differences between the urban culture of the north (with major towns like Liège, Namur and Nivelles) and the more traditional estate economy of the principalities of Namur and Luxemburg.

\section{THE SOCIAL MULTIFORMITY OF IRON PRODUCTION}

Iron production, like the textile trade, may be looked upon in terms of branches of an industry rather than a single homogeneous one. The analysis ought to be accomplished on a level that takes the whole chain of production into account. Among other things this implies an attempt to break up the rather artificial distinction between the urban and rural stages of production. ${ }^{2}$

\footnotetext{
1 The comparison between Russia and Sweden is mainly based on discussions within a current comparative project with Swedish and Russian historians. This means that many of the references are made to manuscripts which are so far unpublished. A conclusive Volume is, however, under preparation.

${ }^{2}$ M. Berg, "Revisions and Revolutions: Technology and Productivity Change in Manufacture in Eighteenth-Century England", in P. Mathias and J. A. Davis (eds), Innovations and Technology in Europe (Oxford, 1991), p. 55. Alain Dewerpe also reflects that the rural and urban parts of production more often were supplementary than exclusive forms

International Review of Social History 39 (1994), Supplement, pp. 83-113
} 
The concept "chain of production" is basically technical, defining the different stages of the production process. For the iron industry it is possible to single out the mining of the ore, the smelting of it to pig iron, and the further refining of the pig iron in the forge to bar iron, which in its turn can be used for manufacturing nails, weapons and other products. With the exception of forging, the technical process of large-scale iron production was similar in all parts of early modern Europe. ${ }^{3}$ For refining of the pig iron in the water-powered forge, two different processes can be discerned, named after their geographical origins as the Walloon and the German methods. In the Walloon process the pig iron, or more accurately the gueuse, which was a huge piece of cast iron, was melted at one hearth (the finery) and then reheated in another (the chafery) while forged to bars under a water-powered hammer. In the German forge smaller pieces of pig iron were used as raw material. This made it possible to perform the two-step process at the same hearth. Nevertheless, the technical gap between the two methods is not to be exaggerated. Many master forgemen were able to handle them both. ${ }^{4}$ The commensurability concerning skill does not, however, nullify the fact that the Walloon method was more complex and demanded a larger work crew as well as consuming larger quantities of charcoal. ${ }^{5}$

Before the nineteenth century it was unusual to find the different stages of production concentrated in the same establishment. The English economic historian Peter Mathias has underlined that a spatial disintegration was typical of the proto-industrial iron industry as a consequence of its need of charcoal and water-power. In Sweden as in Walloonia there were clear-cut geographical distinctions between regions with mines

of organizing work, A. Dewerpe, L'industrie aux champs. Essai sur la proto-industrialisation en Italie du Nord (1800-1880) (Rome, 1985), p. 31.

${ }^{3}$ Here speaking of the so-called indirect method which during the latter part of the Middle Ages in many regions had replaced the direct method. In the indirect method the ore became totally liquid due to the higher temperature in the furnace obtained by the water-driven bellows. R. F. Tylecote, The Early History of Metallurgy in Europe (New York, 1987), p. 330. N. Björkenstam, Västeuropeisk järnframställning under medeltiden (Stockholm, 1990), p. 70. Spain was an exception from this general development. Bloomeries, of a refined sort, were thus still dominant during the eighteenth century. In many other regions, however, the two methods coexisted for several centuries. For Spain, see, E. F. de Pinedo, "From the Bloomery to the Blast-Furnace. Technical Change in Spanish Iron-Making (1650-1822)", Joumal of European Economic History, 17 (1988), p. 23.

4 This fact was clearly shown by the Walloon emigrants that arrived in Sweden during the first decades of the seventeenth century, and of whom some continued to use their traditional methods while others were employed at ironworks using the German method. $s$ The efforts to effect a change-over from Walloon to German forging in eighteenth-century France - as a consequence of the problems with the support of charcoal - illuminate an important aspect of the difference. S. Benoit, "La consommation de combustible végetal et l'évolution des systémes techniques", in D. Woronoff (ed.), Forges et Forets. Recherches sur la consommation proto-industrielle de bois (Paris, 1990), p. 95. 
and furnaces on the one hand and regions dominated by forges on the other. This decentralized structure of production evidently created transport problems. Russia seems to be an exception to this pattern and thus undermines Mathias's assertion that dependence on both charcoal and water-power explains the industrial disintegration. ${ }^{6}$ The units in the Urals were centralized plants which as a rule included both furnace, forge and sometimes also manufacturing workshops. Some of them were of an impressive magnitude. In the middle of the eighteenth century the ironworks at Serebrjansk for example worked 12 hammers; and within a 50-kilometre radius around one the of the oldest ironworks in the Urals, Neviansk, 8 furnaces and about 30 hammers were at work. ${ }^{7}$

The technical and spatial aspects of production shaped the framework of the organization of the labour force. In all three regions the major part of it was employed in the peripheral parts of the production - i.e. with mining, charcoal burning and transportation - while industrial work in the furnaces and forges demanded comparatively. few workers. We can also note some general similarities concerning the social organization of work, as more or less proletarian groups of peasants played the quantitatively most important role while skilled and professionalized workers were employed in the actual production of iron. However, viewed in greater detail, the differences between the regions are more striking than the similarities.

\section{BERGSLAGEN}

$\mathrm{U}_{\mathrm{p}}$ to the seventeenth century the peasants that lived in the ironproducing region of the Bergslagen (Figures 1 and 2), made up the social base for the production of iron. The rather static nature of such a peasants' corporation could, however, by no means efficiently respond to the rise in demand that occurred on the international market during the seventeenth century. The tenfold increase in the export of bar iron from Stockholm that is perceivable during the century, was instead due largely to a massive influx of foreign merchant capital and its investment,

"P. Mathias, "Resources and Technology", in Mathias and Davis, Innovations and Technology, p. 20. Even more pronounced in E. A. Wrigley, Continuity, Chance and Change: The Character of the Industrial Revolution in England (Cambridge, 1988), ch. 1. See also the discussion in P. Verley, "La révolution industrielle Anglaise, une révision (note critique)", Annales E.S.C., 46 (1991). To the Russian case of the eighteenth century one could also add Maxine Berg's discussion of the Canadian and Swedish development during the process of industrialization as contradictory to the Mathias-Wrigley thesis. Berg, "Revisions and Revolutions", p. 56.

'R. Portal, L'Oural au XVIlle siecle (Paris, 1950), p. 136; N. A. Minenko et al., "Ural Iron before the Industrial Revolution", in G. Rydèn and M. Agren (eds), Ironmaking in Sweden and Russia, A Survey of the Social Organisation of Iron Production before 1900 (Uppsala, 1993), p. 68. 
mainly in forges. ${ }^{8}$ The result was thus a socially divided industry, where the mining peasants remained in control of mines and furnaces, but lost influence over the production of bar iron. Up to the middle of the eighteenth century the peasants thus dominated the production of pig iron, and concerning the mines the penetration of the trade by industrial capital is, in most areas, a phenomenon of the nineteenth century. ${ }^{9}$

In the household of the mining peasant the hours of work were divided between mining, charcoal burning, transportation,-production of pig iron and agricultural work. To a great extent their economy was selfsupporting. On the other hand, forges owned and administered by merchants and industrialists created a demand for charcoal and transport, tasks that had to be undertaken by groups of peasants that were not themselves producers of iron and to a certain extent forcible means were used to make them fulfil these obligations. Peasants that lived on lands bought. by the newly established ironworks paid their feudal rent in charcoal. The Crown, which favoured the influx of merchant capital and the rise in iron production, also transferred certain fiscal rights to the ironmasters, who transformed them into taxes to be paid in charcoal or labour. A substantial part of the need, however, was appeased by the market, and the workforce thus was made up of peasants that voluntarily produced and sold their charcoal to the ironworks. ${ }^{20}$ To avoid competition and to hold prices down on raw materials, this market was, from the end of the seventeenth century, firmly directed by the state. ${ }^{11}$ The policy was carried out by a separate administration that was created in 1637 for the iron industry: the Board of Mines.

Charcoal burning and transport were as a rule supplementary to agricultural work. The combination of purely agrarian and semi-industrial

${ }^{8}$ K.-G. Hildebrand, Swedish Iron in the Seventeenth and Eighteenth Centuries. Export Industry before the Industrialization (Stockholm, 1992), pp. 24-26; A. Florén et al., "Swedish Iron Before 1900", in Rydén and Agren, Ironmaking, pp. 22-24. The investment of merchant capital followed the typical pattern described by among others Fernand Braudel, implying that the merchant strived for a monopolization of the strategic part of the chain of production from which he could control the international market. F. Braudel, Marknadernas spel. Civilisationer och kapitalism 1400-1800, vol. 2 (Stockholm, 1986), p. 299.

This sort of peasant-based iron production also survived in several regions in the German lands up until the industrial revolution. H. Kellenbenz, "Europäisches Eisen. Produktion Verarbeitung - Handel (Vom Ende des Mittelalters bis ins 18. Jahrhundert)", in Kellenbenz (ed.), Schwerpunkte der Eisengewinnung und Eisenverarbeitung in Europa 1500-1650 (Cologne, 1974), p. 409; M. Mitterauer, "Produktionsweise, Siedlungsstruktur und Sozialformen im österreichischen Montanwesen des Mittelalters und der frühen Neuzeit", in Mitterauer (ed.), Osterreichisches Montanwesen. Produktion, Verteilung, Sozialformen (Vienna, 1974), p. 313.

${ }^{20}$ Hildebrand, Swedish Iron, pp. 86ff.

1. Florén et al., "Swedish Iron Before 1900", p. 34; P.-A. Karlsson, Järnbruken och St\&ndssamhället. Institutionell och attitydmässig konfikt under Sveriges tidiga industrialisering 1700-1770 (Stockholm, 1990), pp. 46-48. 

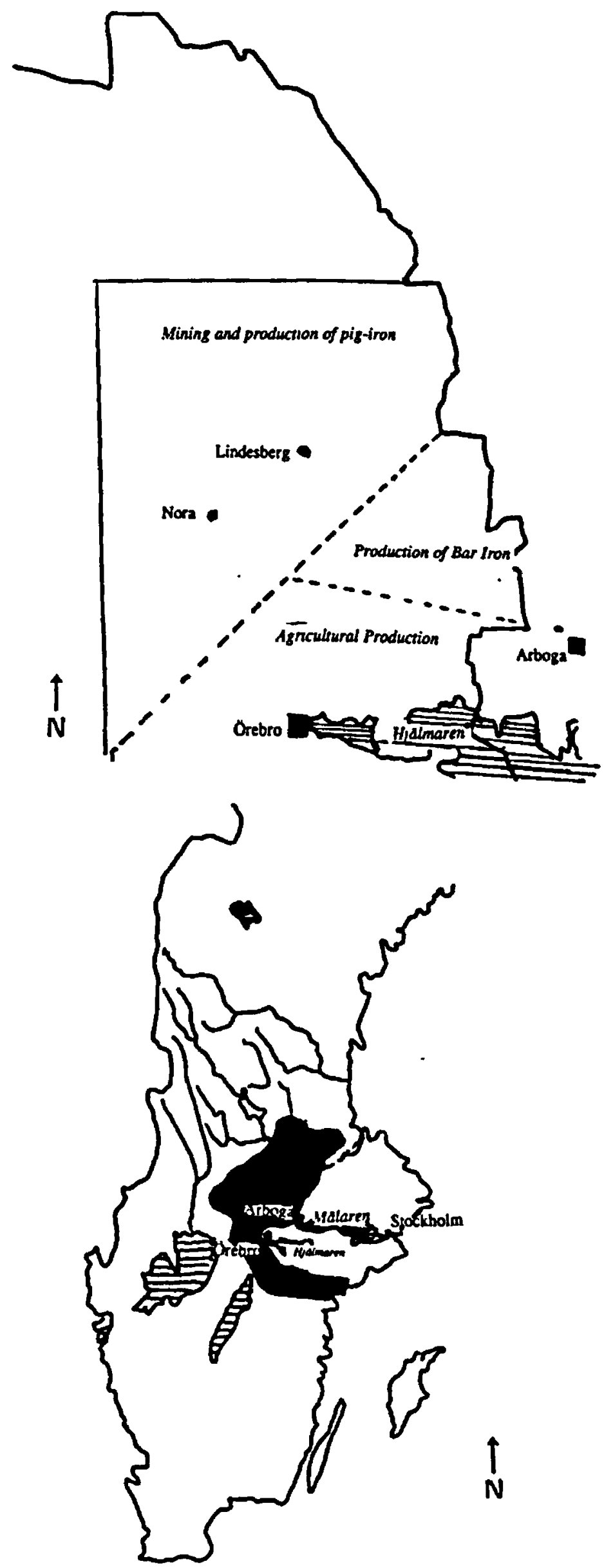

Figure 1. The traditional iron-producing region in Sweden, Bergslagen, forming a crescent around the valleys of lakes Malaren and Hjalmaren 
work in the household was thus kept unbroken and the different operations were neither specialized nor supervised by the ironmaster. ${ }^{12}$ During the latter part of the eighteenth century the situation began to change. The ironworks had, on a much larger scale than before, made investments in woodlands and now strived to establish a system with charcoal cotters to secure the necessary raw materials. The furnaces were collectively owned and maintained by the mining peasants, but worked individually. Each peasant proprietor thus used it for melting his own ore, using his own labour force and supply of charcoal. At the beginning of the seventeenth century, the mining peasants themselves worked in the furnace. In order to control the quality of the product by supervising production, it was, however, during the middle of the century, stated that the proprietors had to hire specially trained experts to be responsible for the production. This meant that a wage relation was implanted in the social organization of work in the furnace, a novelty imposed from above, namely by the state. The mining peasants, however, still performed the more unqualified tasks in the furnace as well as accomplishing the necessary transportation. They also sold the pig iron to ironmasters or merchants. During the second half of the eighteenth century the state's direction of the pig iron market became more resolute. In reality there already existed restraints, but of a different nature as the mining peasants were often bound to the ironmaster economically. Generally the peasants were unable to produce enough foodstuff to support their rather large households on the poor soils in the mining districts, so the ironmasters advanced them money or goods. The relation between the producer of pig iron and the ironmaster often, therefore, took the form of a Kaufsystem. ${ }^{13}$

The forges were as a rule small and rather isolated establishments situated in the countryside. The master forgemen with their crew lived near the forge in houses that were often let to them by the ironmaster and were supported with foodstuff from the company's store. From the patron they also obtained small allotments of land on the ironworks' estate. ${ }^{14}$ These small communities came to form rather closed paternalist

12 The long winter of the Nordic countries extended the period of underemployment for the cultivators and made it possible to spread the different occupations over the year. This meant that the household's structure could be kept intact and that work for the iron industry could be done alongside ordinary work. For the size of the households see $D$. Gaunt, "Familj, hushall och arbetsintensitet. En tolkning av demografiska variationer $i$ 1600- och 1700-talens Sverige", Scandia, 44 (1976), p. 53. For the working conditions, Hildebrand, Swedish Iron, p. 92.

${ }^{13}$ M. Sjobberg, Järn och Jord. Bergsmän pd 1700-talet (Stockholm, 1993), ch. 5.

14 G. Ryden, "Iron Production and the Household as a Production Unit in NineteenthCentury Sweden", unpublished paper at the Cambridge Group for the History of Population and Social Structure (May 1993), p. 29. 


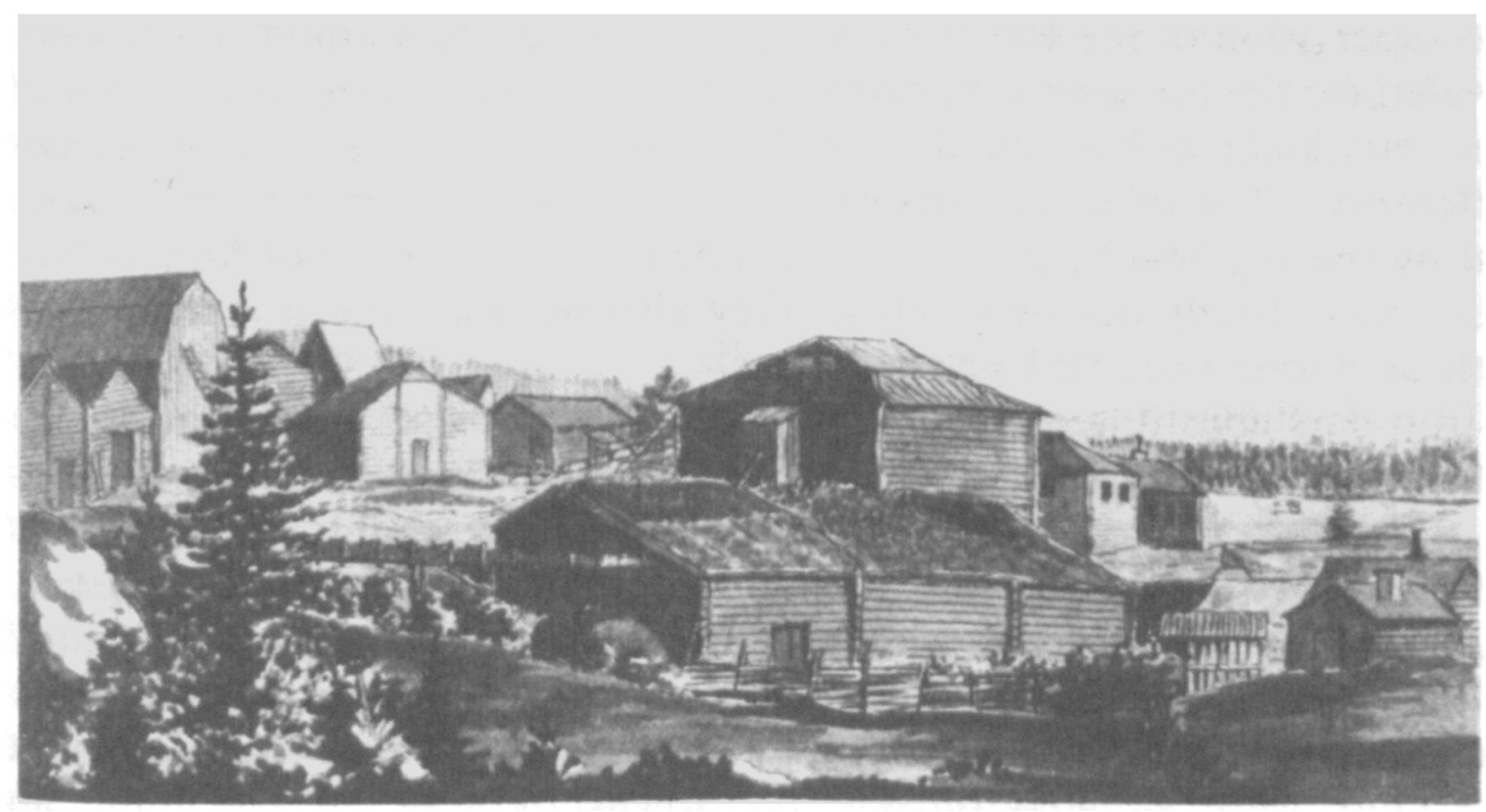

Figure 2. The Greksåsar village in the mining district of Nora (Bergslagen) in 1846. The blast furnace is situated in the centre and the smaller buildings surrounding it are stores for iron and charcoal. The drawing gives an impression of the spatially dispersed and socially differentiated Swedish industry in contrast to the centralized uralian premises (Photo: Jernkontoret's bruksbildskatalog)

unities, ironworks communities, during the latter part of the eighteenth century. ${ }^{15}$

Even if the forge was owned by the ironmaster and not by the master forgeman, the latter nevertheless often maintained a rather independent position. During the seventeenth and first half of the eighteenth century many of the master forgemen worked on a subcontracting basis and were themselves responsible for the maintenance of the workshop, hiring of journeymen and apprentices as well as purchasing charcoal and sometimes even pig iron. ${ }^{16}$ During the eighteenth century he was as a rule provided with raw materials by the ironmaster and had to have the ironmaster's permission before hiring new workers. As his skill was necessary for the production, the master forgeman, however, maintained a strong position at the shop floor level. ${ }^{17}$

A separate jurisdiction for the mining peasant is mentioned as early as the Middle Ages. In the seventeenth century it was reorganized under

is A. Florén and G. Rydén. Arbete hushall och region. Tankar om industrialiseringsprocesser och den svenska jarnhanteringen (Uppsala, 1992), p. 102. The same development has been discussed for the French iron industry. P. Bernard. "Une architecture pour les forges?" in D. Woronoff (ed.), La Métallurgie du fer dans les Ardennes (XVIe-XIXe) (Paris, 1988). p. 85; see also D. Woronoff, L'industrie sidérurgique en France pendant La Revolution et L'Empire (Paris, 1984), p. 182.

16 Florén and Rydén. Arbete hushall och region, p. 46.

"G. Rydén. "Skill and Technical Change in the Swedish Iron Industry, 1750-1850". unpublished paper at the conference on Technological Change, University of Oxford, 811 September 1993 
the supervision of the Board of Mines, and at the same time courts were created for the forgemen. In many respects the courts were reminiscent of the traditional artisan guild, but, however, there were also important differences. The mining courts were ruled not by its corporate producers, but by the regional authorities subordinated to the Board of Mines. Nor were they strictly professional, as they also included the ironmasters as well as apprentices and journeymen. ${ }^{18}$

Iron bars constituted the dominant product in the export of iron. The share of more refined products in the trade rose during the last decades of the eighteenth century, but even before that period establishments for manufacturing iron were built up to support the national market, and not least the Crown, with products. Generally they were situated in the countryside and often populated with workers from abroad, from Germany or Walloonia, or from the surrounding cities. The fact that the units were situated outside the towns did not always imply an absence of corporate guild-like organizations. At the ironworks at Jäder, as well as at the Vira works, traditional artisan guilds persisted during the seventeenth century. These corporations, however, were reshaped during the following century and given a more patriarchal form, in which organizations the owners of the works were secured an influential role. ${ }^{19}$

\section{WALLOONIA}

The first expansion of the industry in Walloonia during the late fifteenth and sixteenth century was highly stimulated by the urban centres of Liège, Huy and Namur. Originally forges and furnaces were often collectively owned by merchants or companies comprising merchants and skilled workers. The dominant line of development, however, was towards a situation where a single merchant, or merchant family, was owner. ${ }^{20}$ During the seventeenth century the heavier branches of the industry, while still flourishing in the lands between the rivers Sambre and Meuse (Entre-Sambre-et-Meuse - an area divided between Liège and the principality of Namur), declined round the cities of Liège and Huy. Simultaneously a second expansion started further south, in the principality of Luxemburg. Capital from Liège was vital for the initial

${ }^{18}$ Florén et al., "Swedish Iron Before 1900", p. 19.

19 A. Florén, "Klasskamp utan fackförening, om fơrindustriella arbetskonflikter", Arkiv för studier i Arbetarrörelsens historia, 45 (1990), p. 14.

$20 \mathrm{~J}$. LeJeune, La formation du capitalisme moderne dans la principauté de Liège au XVIe siecle (Liège, 1939), p. 230; G. Hansotte, "La métallurgie Wallone au XVIe et dans la premier moitié du XVIIe siècle", in Kellenbenz, Schwerpunkte der Eisengewinnung, p. 138; F. Discry, "L'ancien bassin sidérurgique du Hoyoux du XVe au XVIIIe siècles", Anciens Pays et Assemblées d'Etats, vol. L (Brussels, 1970), p. 59. A similar development is also visible in the Spanish iron industry during the sixteenth and seventeenth centuries. See E. F. de Pinedo y Fernández, "Centros de la industria siderurgica en el pais vasco", in Kellenbenz, Schwerpunkte der Eisengewinnung, p. 87. 
phases of the development of the large-scale industry in the new territory. However, it also had its own logic, gaining a somewhat more seigneural aspect. Thus the ironmasters often gained noble titles and invested considerable sums of capital in large estates. ${ }^{21}$

It" is probable that the ironmasters of Luxemburg were able to use their seigneurial rights to facilitate the construction of the ironworks as well as the support of charcoal and transport. The importance of such a -feudal relationship should, however, not be exaggerated. Accounts from the eighteenth century indicate that raw materials and transports were bought from groups of peasants. ${ }^{22}$ Certainly less numerous than in the north of the Netherlands, i.e. in Brabant or Flanders, there nevertheless existed a rural proletariat in the iron-producing regions that could be enrolled for unskilled or semi-skilled work for the ironworks. ${ }^{23}$ During the second half of the eighteenth century, for which period the sources are able to give us a clearer picture, we thus find both specialized wood-cutters, transporters and charcoal burners. The households were not totally proletarized since they still cultivated some land, but were heavily dependent on the income from the ironworks. ${ }^{24}$

If compared with the Swedish example, the structure of trades seems to have been rather specialized. Wood-cutters were distinguished from

${ }^{21}$ Hansotte, "La métallurgie Wallonne", p. 130; G. Hansotte, "L'implantation géographique de l'industrie métallurgique des Pays-bas et du Pays de Liège et son évolution aux temps modernes", in M. Dorban et al. (eds), Implantations Industrielles. Mutations des Sociétés et du Paysage (Brussels, 1986), p. 44; M. Dorban, "Les débuts de la révolution industrielle", in H. Hasquin (ed.), La Belgique Autrichienne, 1713-1794 (Brussels, 1987), p. 128.

${ }^{22}$ G. Hansotte, "Un compte des Fourneaux d'Ansembourg et des Forges de Septfontaines, 1761-1764", Bulletin Trimestriel de L'institut Archéologique du Luxembourg (1977), pp. $38-40$.

${ }^{23}$ P. Moureaux and J. Ruwet, "Rester districts. Les Pays-Bas de 1421 a 1794", in L. Genicot (ed.), Histoire de la Wallonie (Toulouse, 1973); C. Lis and H. Soly, Poverty and Capitalism in Pre-Industrial Europe (Hassocks, 1979), p. 15. It is also plausible that the iron industry had a positive effect on the increase of this group by a raise in weddings and a lowering of the age of marriage. M. Dorban, "La sidérurgie Luxembourgeoise au XVIIIe siècle", in La sidérurgie aux XVIIIe et XIXe siècles: aspects techniques, économiques et sociaux (Louvière, 1985), pp. 26-27.

${ }^{24} M$. Dorban, "Les communautés rurales dans la vallée de la Haute Semoise (15001800)" (unpublished doctoral dissertation, Université Catholique de Louvain, 1983), pp. 428-447; M. F. Piret, "Fortunes et Groupes Sociaux: Habay-la-Neuve 1766-1796" (unpublished dissertation, Université Catholique de Louvain, 1982), p. 186; A. Florén, "Gruvornas, Hyttornas och Hamrarnas folk i Lorraine Belge vid 1700-talets mitt" (manuscript 1993). Often they owned the equipment necessary for fulfilling their tasks. However, there existed exceptions to this general picture. At the monastery at St Hubert in the Ardennes, the legendary Abbot Nicolas Spirlet, who in the second half of the eighteenth century made an impressive effort to establish an integrated metallurgical plant near the monastery, tried to solve the problem of transport by letting horses and donkeys to the rural poor in the surrounding area. R. Evrard, Dom Nicolas Spirlet, Mastre de forges a Poix, au Chatelet et aut Fourneau Saint-Michel (Liège, 1952), p. 21. 
the workers that put up the charcoal kiln and they in their turn from the burners. There are also traces of a guild-like structure of work. The sources are thus referring to master-cutters and apprentices, master charcoal burners, etc. This certainly points to how skills were communicated in the trade, but it is uncertain if the hint also refers to the existence of an actual corporate organization or if, which is more probable, it is rather a question of a "guild language". ${ }^{25}$ In this line of argument it is important to underline that there is no evidence of supervision of the work by the ironmasters. ${ }^{26}$ Mining was organized in the same small-scale and autonomous way. The miners worked in crews of two or three one person working down the pit and the other bringing up the ore and they then sold the mineral to the ironworks. When a pit was filled with water or empty of iron ore, it was abandoned, and a new one was soon taken up."

As in the Bergslagen region it was quite rare to find ironworks with both furnace and forge. ${ }^{28}$ The plants, despite the more dense rural population, in fact give the impression of an even greater isolation in Walloonia, though neither houses nor stores or other communal establishments for the workers were constructed by the ironmasters. Skilled workers, as well as miners and charcoal burners, were instead integrated in the nearby village communities of the countryside and had rights to common lands, meadows and forests. ${ }^{29}$ Workers' dwellings were thus separated both geographically and socially from the actual ironworks. There are, in other words, no traces of the sort of paternalistic setting that during the first decades of the nineteenth century came to dominate the coal mining communities in Belgium as well as in the large-scale iron industry round Liège. ${ }^{30}$

${ }^{25}$ Compare the discussion in Woronoff, L'industrie siderurgigue, p. 140 on the situation in late eighteenth-century France.

${ }_{26}$ F. Pirotte, La terre de Durby aux XVIIe et XVIIIe siècles (Louvain, 1974), p. 186. In France, however, Denis Woronoff has indicated a development away from such a situation during the end of the eighteenth century, towards a system that permitted the ironmasters to have a firmer control over production. Woronoff, L'industrie sidérurgique, p. 138.

${ }^{27} \mathrm{M}$. Caulier-Mathy, "Les maîtres de forges wallons contre la loi imperiale sur les mines, première phase", in La siderurgie, p. 38. The pits were holes with a diameter of some 3 or 4 feet, which during bad weather were covered. At the beginning of the nineteenth century a French mining engineer remarked that the sight of the mining areas most of all reminded him of a military camp filled with tents. A.-M. Damin, "La métallurgie dans le Namurois 1764-1814. Etude économique et sociale" (unpublished dissertation, Université Catholique de Louvain, 1967), p. 263.

${ }^{23} \mathrm{G}$. Hansotte, La métallurgie et le commerce international du fer dans les Pays-Bas autrichiens et la Principauté de Liège pendant la seconde moitié du XVIIJe siècle (Brussels, 1980), ch. III.

${ }^{29}$ C. de Moreau de Gerbehaye, "Les forges du bassin de la Rulles au XVIIle siècle", in La sidérurgie, p. 11. See also Woronoff, L'industrie sidérurgique, p. 140.

${ }^{30} \mathrm{R}$. Evrard, Forges Anciennes (Liège, 1956). For the coal mine communities see $\mathrm{H}$. Watelet, Une industrialisation sans development. Le bassin de Mons et le charbonnage de Grand-Hornu du milieu de XVIIle siecle au milieu du XIXe siecle (Louvain, 1980), p. 332; R. Leboutte, "La condition ouvrière en Wallonie aux XVIIIe-XIX siècles", Cahiers 
The labour force at the forges were, due to the technical difference, larger than in Sweden but their social position seems similar. During the sixteenth century the contracts of the skilled workers at the furnaces and forges in the Huy-Liège area thus give an impression of their rather independent position. Here there are obvious traces of a tradition, where the forgemen also were engaged as charcoal burners or miners and thus themselves were directly responsible for the acquisition of raw materials. ${ }^{31}$ This situation altered during the succeeding centuries to a more professionalized structure. The social system, as in the Swedish case, thus tended to take the form of what can be distinguished as a centralized putting-out. ${ }^{32}$ Even if the ironmasters advanced the raw materials to the workers, no overseers or workers specializing in the maintenance of the workshops are mentioned among the staff at the ironworks. ${ }^{33}$ In certain, but not all, parts, the skilled workers of the industry were organized in a corporate manner, which among other things meant that a separate jurisdiction was created. ${ }^{34}$ The most famous example is the court of the metal trades in Namur, Cours de Ferons, which had full jurisdictional rights over its subjects, meaning that it also dealt with criminal justice. ${ }^{35}$ Unlike the Swedish jurisdiction, the courts in Namur were not subordinated to a central body of administration - a fact which is intelligible

de Clio (1987), pp. 28, 34. Despite these characteristic features of the Walloon industry, it has been argued that the truck system was also practised at the ironworks in the province of Luxemburg during the eighteenth century. P. Moureaux, "Truck-system et revendications sociales dans la sidérurgie luxembourgeoise du XVIIIe siècle", in Mélanges offerts d G. Jacquemyns (Brussels, 1968), pp. 527-530. Nevertheless this does not in itself indicate the all-embracing power over the workers and their families that the concept of paternalism normally implies. S. Pollard, "Factory Discipline in the Industrial Revolution", Economic History Review, 16 (1963-1964), p. 267; Florén, "Klasskamp utan fackförening", p. 18.

${ }^{31}$ J. LeJeune, La formation du capitalisme moderne, p. 148; F. Pirotte, "L'industrie métallurgique de la terre de Durby de 1480 a 1625 , ses rapports avec la métalurgie liégeoise", Bulletin de l'institut archéologique Liégois (1967), p. 156.

${ }^{32}$ R. Evrard and A. Descy, Histoire de l'usine des Vennes (Liège, 1948), p. 64; J. Yernaux, La métallurgie liégeoise et son expansion au XVIle siècle (Liège, 1939), pp. 67, 267, 297, 301; R. Leboutte, La Grosse Forge Wallonne (du XVe au XVIIIe siècle) (Liège, 1984), p. 49.

${ }^{3}$ Damin, La métallurgie, p. 130.

${ }^{34}$ M. Masoin, "Les privileges des férons de Namur sous l'Ancien Régime", Annales de la sociêté archéligique de Namur (1927); Pirotte, "L'industrie métallurgique", p. 150. The same thing is perceivable in late medieval France. See P. Braunstein, "Le travail minier dans le Royaume de France à la fin du Moyen Age", in K.-H. Ludwig (ed.), Bergbau und Arbeitsrecht (no place given, 1989), p. 167. The Belgian historian Marcel Bourguignon has noted that the history of the proto-industrial iron industry shows clear corporate tendencies. Bourguignon, "La sidérurgie, industrie commune des pays d'entre Meuse et Rhin", Anciens Pays et Assemblées d'Etats, vol. XXVIII (Brussels, 1963), p. 93.

${ }^{33}$ Masoin, "Les privileges", pp. 49, 56. This caused problems of demarcation with the ordinary jurisdiction. In 1614 it was complained that the workers committed crimes and excesses but refused to submit to ordinary justice, proclaiming their medieval corporate privileges. See P. Lahaye, Inventaire analythique de pieces et documents contenus dans la correspondance du conseil provincial (Namur, 1892), p. 221. 
from the generally weak and disintegrated nature of the state in the region. ${ }^{36}$

A large part of the bar iron produced in Luxemburg and in the Entre-Sambre-et-Meuse region was transported to be further refined in the flourishing nail and armament industries in the Liège area. During the eighteenth century Charleroi, in the Austrian Netherlands, took up the competition for Liège's hegemonic position (see Figure 3). Behind the rise of both industrial centres lay their resources of coal but also their abundant population of subsistence or nearly landless peasants. ${ }^{37}$ - To facilitate manufacture, the iron bars were transformed to finer dimensions in slitting mills, often owned or hired by semi-independent entrepreneurs, and were then, as in a traditional putting-out system, let over to the peasant nail- or gunsmith who refined the iron bars to consumer products which were handed over to the merchant to be sold at market. In Liège a middleman, martchote, was often used for the transportation to and from the peasant producer. ${ }^{38}$ Normally the investment in fixed capital for the merchant seems to have been rather negligible. ${ }^{39}$ As is common in this type of rural industry the producers were mainly tied to the merchants by bonds of debt, bonds that tended to be deepened by a frequent use of the truck system. ${ }^{40}$ When, for example, the merchant Antoine Succa from Liège sold his nail-making

${ }^{36}$ Such a central administration was first organized during the French rule over the Belgian territory in the beginning of the nineteenth century and it must be underlined that the creation of the Bureau des Artes et Manufactures also was a novelty for the French iron industry. Woronoff, L'industrie siderurgique, p. 40. On the industrial policy and iron production in France during the earlier period, see P. Léon, "Reflexions sur la sidérurgie Française à l'époque ante-colbertienne (1500-1650)", in Kellenbenz, Schwerpunkte der Eisengewinnung. For the policy in Walloonia see H. Hasquin, "Les intendants et la centralisation administrative dans les Pays-Bas méridionaux aux XVIIe et XVIIIe siècles", Anciens Pays et Assemblées d'Etats, vol. XVVII (Brussels, 1968); P. Moureaux, Les Préoccupations Statistiques du Gouvernement des Pays-Bas Autrichiens (Brussels, 1971), pp. 41ff.; H. Soly, "Social Aspects of Structural Changes in the Urban Industries of Eighteenth-Century Brabant and Flanders", in H. van der Wee (ed.), The Rise and Decline of Urban Industries in Italy and in the Low Countries (Louvain, 1989), p. 243.

${ }^{37}$ M. P. Gutmann, War and Rural Life in the Early Modern Low Countries (Assen, 1980), p. 109; N. Haesenne-Peremans, La pauvreté dans la région liégeoise d̀ l'aube de la révolution industrielle (Paris, 1981), pp. 59-60.

${ }^{38}$ G. Hansotte, La clouserie Liégeoise et la question ouvrière au XVIIIe siècle (Brussels, 1972), p. 10.

39 There existed, however, exceptions to this general impression, as the merchant Laurent Butbach who at the end of the sixteenth century with his furnaces, forges, slitting mills and nailers built up a socially, but not geographically, uniform company. R. Evrard, "Laurent Butbach, un précurseur de l'intégration verticale", Revue économique wallon (1963).

${ }^{40}$ Hansotte, La métallurgie, p. 179; H. Hasquin, Une mutation: le pays de Charleroi atux XVIle et XVIIIe siècles (Brussels, 1971), p. 74. 


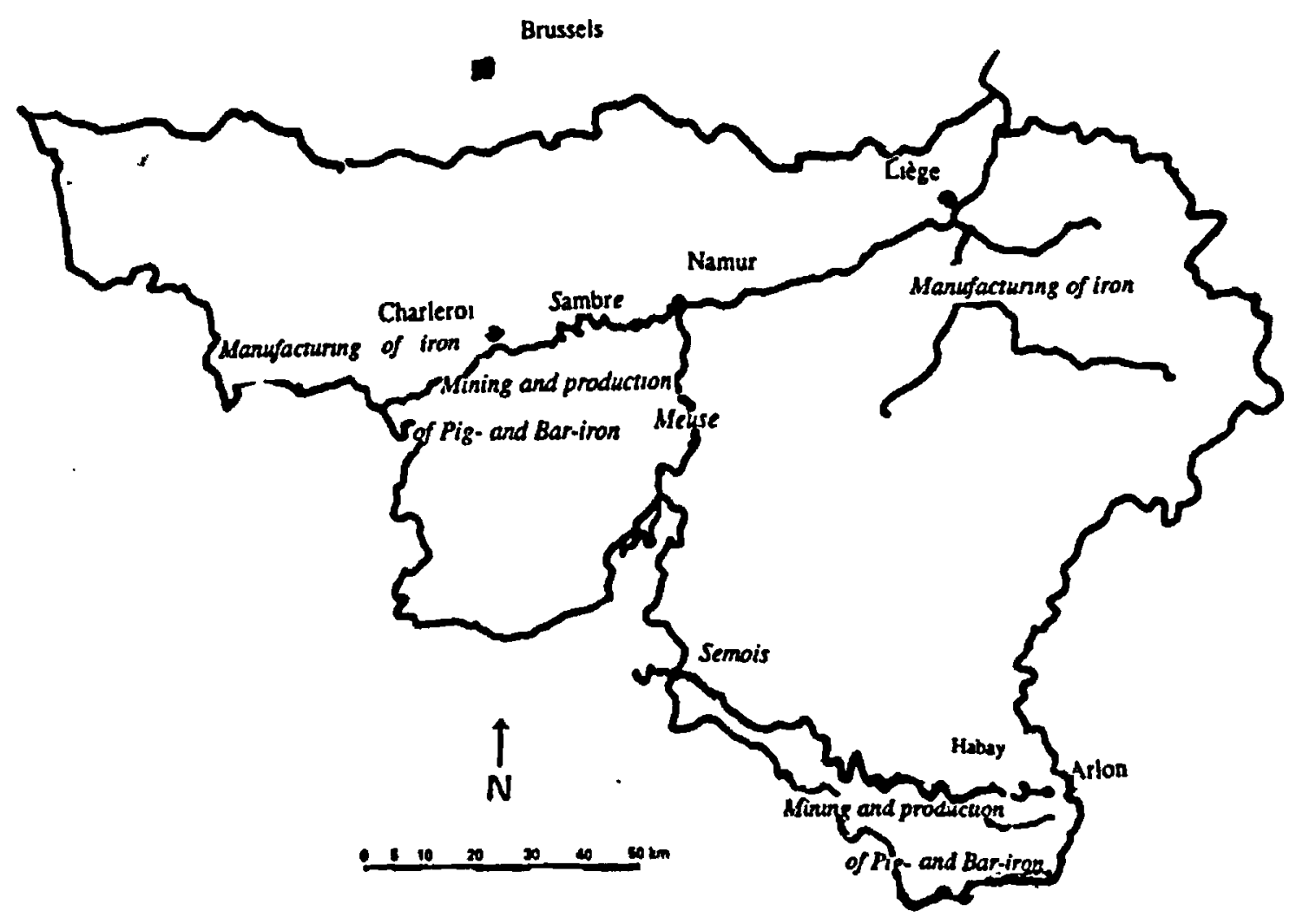

Figure 3. Main iron-producing regions in mid eighteenth-century Walloonia

firm to the widow Catherine Beckers in 1635, it basically consisted of a collection of economic claims on fifty-three different nailers in the area. $^{41}$

\section{THE URALS}

The Russian iron industry expanded rapidly during the first half of the eighteenth century, due to the establishment of large-scale units in the Urals. The main product was bar iron. Some of it was refined locally but the major part was transported to the western part of Russia to be exported or further refined in the armament industry in Tula, south of Moscow, or in the immense works at Systerbeck in Ingermanland. ${ }^{42}$

The Tsarist state was the leading promoter of the development and also dominated as proprietor. In order to rule the different works, a

"Yernaux, La métallurgie liégeoise, p. 311.

${ }^{42}$ The Swedish traveller Daniel Tilas gave a colourful description of the immense works at Systerbeck in Russian Ingermanland with its seventeen workshops among which the establishment for the production of sword-blades alone took up eighteen hearths in a line. According to Tilas the plant daily employed 500 workers; however, he also remarked that the works were only activated when the Tsar wanted to show the establishment to foreign visitors in order to "prove to foreigners that Russia also owned such establishments". D. Tilas, "Kort beskrivning om en inom ryska grïnsen gjord resa 4/2-6/4 1738", unpublished manuscript in the archives of the Board of Mines, at the Royal Archives in Stockholm. 
special administration, modelled on the Swedish Board of Mines, was organized. ${ }^{43}$ During the latter part of the eighteenth century many of the state-owned works, however, were sold to the aristocracy. Even more marked than before, the ironworks then became an integral part of a feudal estate economy.

The organization of the industry in the virgin Siberian lands met with large problems, not least the problem of how to create a substantial labour force. As a rule peasants were recruited by feudal and forcible means. They were either serfs bound to the ironworks or conscripted state peasants who paid their taxes as labour-rent at the industrial establishments of the Tsar or of private owners. ${ }^{44}$ Conscription meant that the peasants left their villages for a period, often of several years, to work at the ironworks, predominantly in the woodlands and mines. Here work was organized on a large scale. Different tasks were specialized and their fulfilment was carefully supervised. The routines were largely the same at both the private and state-owned works. For example at the ironworks of the Demidov family ${ }^{45}$ in Nizhny Tagil charcoal burning was carried out by different crews of peasants, one for each separate stage of the production. A group of 700 wood-cutters prepared the logs which were used by another crew to construct the charcoal kiln and then the charcoal was burned by a third group of peasants under the supervision of skilled charcoal burners. During the eighteenth century attempts were made to constrain the work of the conscripted peasants to the technically less demanding parts of the production, while skilled charcoal burners took over the work at the kiln. ${ }^{46}$ The work in the

4 Contrary to the Swedish administration the Russian one was mainly restricted to supervision over the state-owned part of the industry. C. Peterson, Peter the Great's Administrative and Judicial Reforms (Stockholm, 1979), pp. 368-370; Portal, L'Oural, p. 41.

4 O. Crisp, "Labour and Industrialization in Russia", in The Cambridge Economic History of Europe, vol. VII-2, p. 311; Minenko et al., "Ural Iron", pp. 71-79. The latter group were paid for their additional work, but their wages were fixed by the owners of the ironworks and not set by the market. In his study of the Bohemian iron industry Milan Myska uses the notion of forced wage labour to distinguish such a social relationship. $M$. Myska, "Pre-industrial Iron Making in the Czech Lands: the Labour Force and Production Relations circa 1500-1840", Past and Present, 82 (1979), pp. 63-65.

${ }_{45}$ The Demodiv family was the biggest private owner of ironworks in the Urals, and presided, in the latter part of the eighteenth century, over a labour force of 21,000 peasants. R. Portal, The Slavs (London, 1975), p. 158. See also H. D. Hudson, The Rise of the Demidov Family and the Russian Iron Industry in the Eighteenth Century (Newtonville, 1986). At the works of Nizhny Tagil 2,500 persons were employed in iron production in the middle of the nineteenth century, not counting the bulk of auxiliary workers. T. Esper, "The Incomes of Russian Serf Ironworkers in the Nineteenth Century", Past and Present, 93 (1981), p. 146.

${ }^{46}$ I. V. Poberezhnikov, "The Charcoal Production in Ural", unpublished manuscript at the third meeting on iron making in Russia and Sweden before the twentieth century, Yekaterinenburg, 1993, p. 5. 


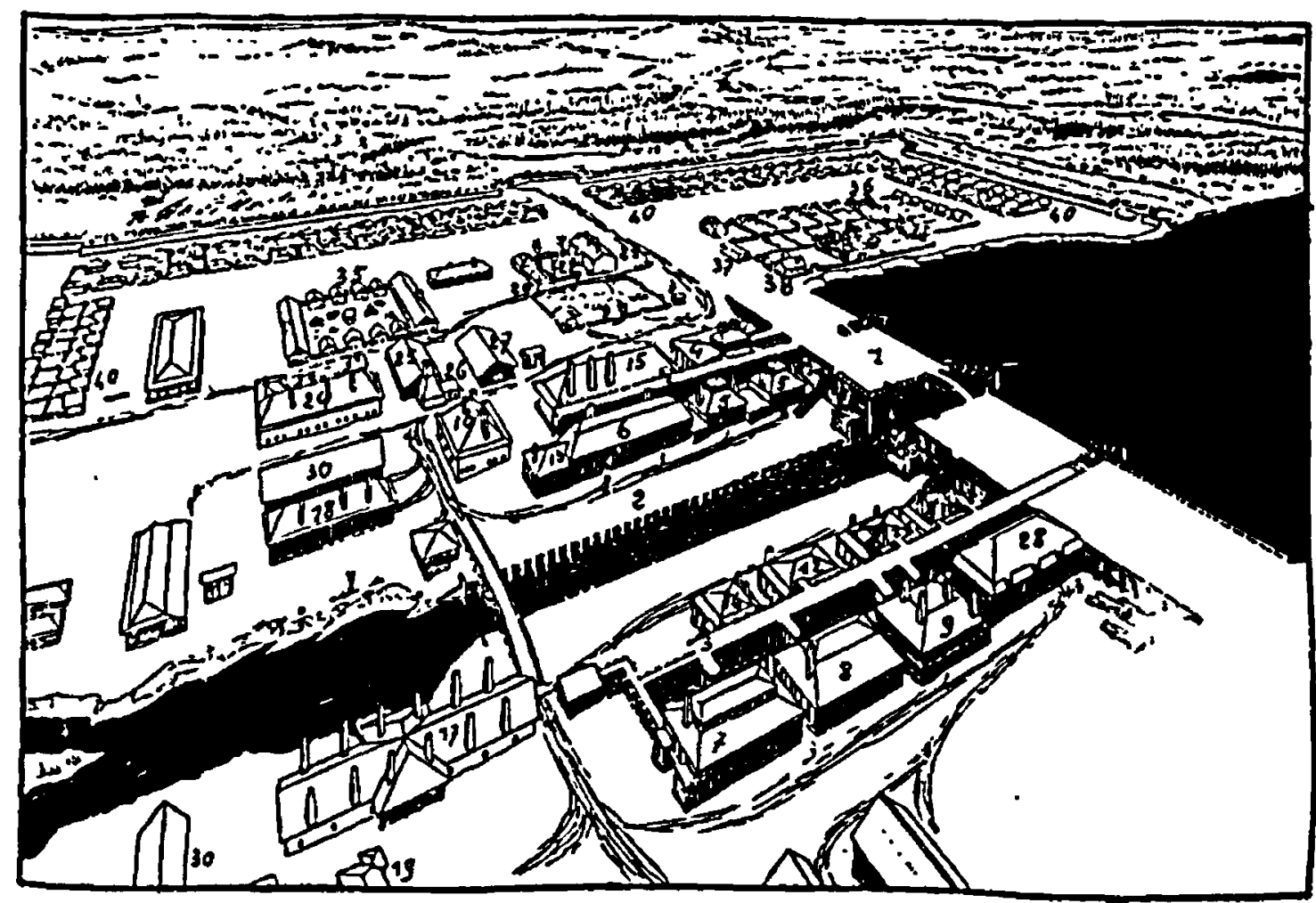

Figure 4. The ironworks in Yekaterinenburg during the first half of the eighteenth century. The establishment was an integrated plant for metallurgical production with a furnace (4), forges $(5,7)$ and a rolling mill $(12)$. It also contained workshops for production of anchors (9), sheet-iron (6), steel $(10,11)$ and wire as well as for the manufacturing of copper (15) and tin (16). The workers lived in the area (40) and had their own church (38) and school (36) and there was also a jail (not possible to locate). The patemalist pattern is thus as evident as the proto-factory pattern. (From Portal, 1950, p. 230)

mines was basically performed on the same large-scale manner. However, there also seems to have existed certain possibilities for groups of peasants, on a subcontracting basis, to work the mines and then sell the ore to the ironmaster. ${ }^{47}$

The ironworks formed separate and closed communities within the estate organization (see Figure 4). Houses for the workers were constructed by their patron along with churches, schools, etc. The workers also freely used land for gardening and hay-making as well as having rights to hunt and fish on the estate of the ironworks. ${ }^{43}$ Many establishments were also fortified, surrounded by walls and having their own military forces. ${ }^{49}$ In spite of the fact that the German method was commonly in use, the forges were considerably bigger than their Swedish and Walloon counterparts, each one of them comprising between four and six hearths.

\footnotetext{
"Minenko et al., "Ural Iron", p. 80. 1. V. Poberezhnikov, "The Basic Organization for Raw Materials in the Ural Iron Industry", paper at the third meeting on iron making in Sweden and Russia before the twentieth century, Yekaterinenburg, 1993, p. 6.

49 Esper, "The Incomes", p. 150.

'Portal, L'Oural, pp. 185-186, 238, 242.
} 
A majority, even among the forge- and furnacemen, were judicially unfree serfs and formed crews that were directly supervised in the workshop..$^{50}$ Both a foreman with a technical responsibility and a supervisor with economic and bookkeeping tasks, were present at each unit. Carpenters as well as blacksmiths and transport workers were also directly connected to the work in each forge. ${ }^{51}$

\section{RESISTANCE AND CONFLICTS}

Focusing the main interest on conflicts and workers' organizations, it is obvious that a cluster of questions is inseparable from the contradictions and tensions that were intrinsic to the social network of production. Mainly due to the lack of research in this field it is impossible to give a conclusive picture of the conflicts in the different regions under study. The aim, therefore, must be restricted to single out some, hopefully, characteristic features in order to formulate a couple of probable hypotheses on the correlation between social organization, resistance and conflict.

As an important tool for such an analysis the distinction between everyday resistance and organized conflicts will be used, as it has been formulated in recent research conducted by, among others, James C. Scott. ${ }^{52}$ With everyday resistance we thus mean a discord which primarily can be seen as an individual or collective non-acceptance of the relations of production. Escapes, frauds and embezzlements were important aspects of this type of conflict or, to use Denis Woronoff's expression: the "guerilla permanent". ${ }^{53}$ The intention of the perpetrator is not crucial for the labelling of the actions as resistance. The fact that they did create problems, as pebbles in the social machinery of production, is enough for the classification. ${ }^{54}$

Everyday discord could be transformed into outspoken and organized protests, a process that demanded both means of collective organization and ideological legitimation. Such a transformation took various shapes. The established picture in previous research, of the pre-industrial relation between employer and employee as one of harmonious familiarity and

so Ibid., p. 236; Crisp, "Labour and Industrialization", p. 313.

s1 S. Ustiantiev, "The Work in the Ural Forge", unpublished paper at the third meeting on iron making in Russia and Sweden before the twentieth century, Yekaterinenburg, 1993.

52 J. C. Scott, Weapons of the Weak. Everyday Forms of Peasants' Resistance (New Haven, 1985), pp. 28-29.

s3 Woronoff, L'industrie sidérurgique, p. 192.

s4 Analogous problems of interpretation have been discussed by John Styles and Maxine Berg. M. Berg, The Age of Manufactures 1700-1820 (London, 1985), p. 309; J. Styles, "Embezzlement, Industry and the Law in England 1500-1800", in M. Berg and M. Sonenscher (eds), Manufacture in Town and Country Before the Factory (Cambridge, 1983), p. 207. 
household-like intimacy, has been revisited by a number of historians. ${ }^{55}$ There is, however, still a tendency to detect a development from a mainly unorganized protest during pre-industrial time to a more organized and institutionalized protest in modern society: a conclusion that partly seems to be based on the fact that historians often have chosen a rather short historical perspective for their studies, restricted to the Industrial Revolution or at least to the nineteenth century. ${ }^{56}$ Consequently a period has been studied when many of the old collective forms for societal life already had disappeared as a result of the expansion of individualist bourgeois society. What is then easily overlooked is the way that traditional values and organizations from the rural and/or artisan world could, up to a certain point, also prove useful for the proto-industrial workers.

\section{BERGSLAGEN}

During the latter half of the eighteenth century the expansion of the iron industry slowed down. Traditionally this has been interpreted as a consequence of the ironmasters' cautious play with their monopolistic position on the world market in order to push up the prices. It is, however, obvious that the industry during this period also met serious problems with the labour force, notably the agrarian part of it. The enlarged demands on the market for foodstuffs and the increase in prices taken together with the rather static and regulated market for charcoal, made the peasants less inclined to work for the iron industry. ${ }^{57}$ The same dynamics were present in the production of pig iron. When grain prices rose more steeply than that of pig iron, the mining peasant was obviously better off concentrating on his agriculture than maintaining his industrial production..$^{58}$ The massive reclamation of virgin lands evident in the regions dominated by mining peasants, exhibits the path that many of the producers chose. ${ }^{59}$

Conflicts were, however, not restricted merely to such a peaceful withdrawal from industrial work but also took the form of collective

ss Florén, "Klasskamp utan fackförening", p. 3; M. Sonenscher, "Journeymen's Migrations and Workshop Organization in Eighteenth Century England", in S. L. Kaplan and C. Koepp (eds), Work in France. Representations, Meaning and Practice (Ithaca, 1986), p. 76. ${ }^{36} \mathrm{D}$. Geary, "Protest and Strike. Recent Research on 'Collective Action' in England, Germany and France", in K. Tenfelde (ed.), Arbeiter und Arbeiterbewegung im Vergleich (Munich, 1986), pp. 364-369.

"M. Isacson, "The Decline of Peasants' Dependence on the Iron Industry", in Metallurgical Works and Peasantry (Yekaterinenburg, 1992), pp. 214-215.

ss Sjöberg, Jän och Jord, p. 123.

${ }^{59} \mathrm{M}$. Isacson, Ekonomisk tillväxt och social differentiering 1680-1860, bondeklasen i By socken (Uppsala, 1979), p. 83; M. Ágren, Jord och Gäld, social skiktning och rättslig konflikt i sódra Dalarna, ca 1650-1850 (Uppsala, 1992), ch. VI; T. Omberg, Bergsmän i hyttelag. Bergsmansnäringens utveckling $i$ Linde och Ramsberg under en 100-drsperiod fran mitten av 1700-talet (Uppsala, 1992), p. 103. 
actions. In order to increase the price of charcoal the peasants who produced and delivered this bulky item to the Leufsta ironworks in central Sweden boycotted the establishment on several occasions between 1718-1720. Similar actions happened in other parts of the country at the same time, as well as later during the eighteenth century.$^{60}$ Other means of protest were also used. Pleas were made at the mining court or, more often, at the ordinary court of the hundred. Peasants obviously chose the jurisdictional arena, where their influence traditionally was stronger.

The Swedish historian Per-Arne Karlsson has related this general movement of increasing dissent to an overall political strengthening of the peasant class during the second half of the century. Swedish peasants had, as a separate estate, always been represented at the Riksdag (the Swedish estate assembly). However, it was during the second half of the eighteenth century that they began acting more independently. The charcoal burners and transporters could profit from the stronger political influence of the peasant estate in their opposition towards the ironworks and their price-pushing policy on transport and charcoal. They were also able to gain political support from other groups, not least merchants and industrialists from other branches, who saw the dominance of the iron industry in the countryside as a restraint to a more variable economic development. ${ }^{61}$

The conflicts were thus based on the peasants' traditional jurisdictional and political organizations. Their complaints and actions caused a structural crisis for the industry. One way of escaping it was to reshape the property relations in a capitalist direction, which meant a firmer engagement by the ironmaster in charcoal burning, mining and pig iron production. The expansion of the ironworks and the owners' investment in woodlands, furnaces and mines during the latter part of the eighteenth century should be viewed from such an angle. During the same period an increase in the rural population together with an enclosure movement, also gave birth to a pauperized substratum in the countryside which made it easier to create a more proletarian organization of work.

In the forges, as well as in the manufacturing branches, the ironmasters' hegemony over production was based on control over the input of raw material and output of refined products, which gave them the power to stop frauds or embezzlements. An important prerequisite for the workers' illicit trade was their position on the shop floor. William Reddy has demonstrated that at the beginning of the nineteenth century the textile workers in France still maintained the position of selling

${ }^{60} \mathrm{M}$. Isacson, "Ironworks, Charcoal and Peasants", unpublished paper presented at the second meeting on iron making in Russia and Sweden before the twentieth century, Uppsala, 1992, pp. 5-6.

62 Karlsson, Jämbruken, ch. VI. 
not their labour but their product. ${ }^{62}$ The decentralized organization of production in the forges accentuated this artisan principle. The master and his crew worked alone at the hearth and could, for example, estimate when it' was possible to go beyond the normal relation between raw materials and product, set up by the ironmaster, and produce a surplus. As this surplus product was seen as a result of their skills, it was regarded as their property which they freely could sell. The political economy of frauds and embezzlement was, however, not only a question of the social and technical organization of production but also of access to the market. That such a market existed is obvious. During the second half of the eighteenth century a group of scythe smiths in the Dalecarlia region, despite the risk of being punished, openly declared that they used bar iron which they bought directly from the forgemen..$^{63}$

Naturally this sort of commerce was strictly forbidden. In accordance with the royal charters for the industry both the seller and buyer should be punished, the former by running the gauntlet. However, not only the stick but also the carrot was used in order to discipline the workers and make them accept that the raw material, even under the process of work, as well as the end product, was always the property of their patron. In the middle of the seventeenth century a special payment for the surplus iron was introduced, a payment that often played an important role in the total income of the forgeman. ${ }^{64}$ Nevertheless the embezzlement continued.

The control of the input and output from the forge was not only in the interest of the ironmaster. As the wages were paid on a piece-rate basis it was the objective of the workers to check that the quantity and quality of the pig iron as well as the weight of the bars were correctly noted by the bookkeeper. Court rolls from the mining jurisdiction confirm that conflicts predominantly were fought over the quality and quantity of the raw materials and the end product. ${ }^{65}$ The corporate outfit of the court also makes it relevant to suppose that it facilitated the

${ }^{62}$ W. M. Reddy, The Rise of Market Culture. The Textile Trade and French Society, 1750-1900 (Cambridge, 1984), pp. 213, 251. Also M. Sonenscher, Work and Wages. Natural Law, Politics and the Eighteenth Century French Trades (Cambridge, 1989), p. 72.

S. Rinman, "Allmogesmidet i Dalarna. 1764 års undersökning", in C. Sahlin (ed.), Jemkontorets bergshistoriska skriftserie, no. 5 (Stockholm, 1936), p. 26. See also M. Isacson and L. Magnusson, Proto-Industrialization in Scandinavia. Craft Skills in the Industrial Revolution (New York, 1987).

64 Florén and Rydén, Arbete hushall och region, pp. 76-77.

6s A. Floren, "Patterns of Crime, Protest and Conflict in the Nora and Linde Mining Region 1650-1720", paper presented at the third meeting on iron making in Russia and Sweden before the twentieth century, Yekaterinenburg, 1993. The picture that John Rule and John Styles have given of the dominance of these type of tensions and conflicts in the eighteenth-century English putting-out industries and proto-factories then holds true also for the Swedish iron industry. Styles, "Embezzlement"; J. Rule, The Experience of Labour in Eighteenth-century Industry (London, 1981), p. 125. 
skilled workers to organize collective protests. Even if collective claims were put forward in the courts (however seldom on a more aggregate level than the workplace level), the general picture is, therefore, that of the individual master forgeman who presents his complaints over the ironmaster, or more often vice versa. As a rule these conflicts were also concluded in the court or by intervention from the Board of Mines, and did not lead to more widespread social unrest. ${ }^{66}$ To prevent the outburst of any uncontrolled actions the authorities, however, found it necessary to restrict the possibilities of workers gathering at market-places before or- after the sessions of the court assembly. ${ }^{67}$ The court thus rather functioned as an institution for the resolution of conflicts, than as a means for the forgemen to carry out an independent guild policy. ${ }^{68}$ The artisan-like position on the shop floor and the possibility to act as seller on the commodity market being decisive for the embezzlement, holds true for a semi-refined product such as bar iron which to be useful had to be further worked by the peasant or a village artisan. To an even higher degree the conclusion ought to be relevant for the manufactured iron-wares: nails, axes, spades, wire, etc. - products that also found buyers among the consumers in the countryside as well as in the towns. In the middle of the eighteenth century a civil servant responsible for the iron-manufactories concluded that one of the main problems for the industry was that the workers did not conscientiously deliver their products to the owners of the industries, but sneaked part of it away to sell on their own behalf, without any control over the quality, to the surrounding urban or rural dwellers, by which the just profit was withdrawn from their patron. ${ }^{69}$

The ironworks at Jäders Bruk is in this context an illuminating example. During the end of the seventeenth century, the volume of blacksmiths' embezzlement here was as high as one fourth of the total production. ${ }^{70}$ This meant that the ironmaster's position on the market, and thereby the basis for his position of power, was seriously challenged by the actions of the producers. The independent iron-manufacturing guilds had eminent possibilities to serve in accordance with the master smiths' interests. ${ }^{71}$ At Jäder the guild was the organizer behind the

${ }^{66}$ Karlsson, Järnbruken, p. 152; Florén, "Patterns of Crime", p. 12.

${ }^{67}$ Florén, "Patterns of Crime", p. 4.

${ }^{68}$ Even if the courts thus were not able to act as proto-trade unions, they obviously could fulfil other functions for the corporation of master forgemen. In the courts a system of poor relief for the masters and their widows was built up. The control of the masters' skill and competence was, beside being in the interest of the state and ironmaster as a form of quality control, also in the interest of the masters as a token of their exclusive position in the hierarchy of workers.

${ }^{6}$ Quoted from Florén, "Klasskamp utan fackförening", p. 109.

${ }^{\text {t }}$ A. Florén, Disciplinering och konflikt. Den sociala organiseringen av arbetet, Jaders Bruk 1640-1750 (Uppsala, 1987), p. 134.

"Florén, "Klasskamp utan fackförening", pp. 14-16. 
masters' massive resistance against the patron's efforts to take a firmer control over the administration of the workshops as well as against his ambition to control the market for their products. The everyday action of embezzlement was transformed to outspoken demands for the right to sell the products independently on the market. ${ }^{72}$ Juridical means were used by the artisans both at the local and the central level. As was the case concerning the peasants during the eighteenth century, the workers at. Jäder also gained support for their cause from other groups; from merchants in the nearby towns as well as from civil servants in the central administration.

To stress their demands, boycotts were organized and the workers also threatened the patron with collectively leaving the ironworks for other employment. At Jäder the threat of massive escape from the ironworks' was taken seriously, and we can easily see why. In the 1640 s when the social organization was transformed in a capitalist direction, one fifth of the master smiths had left the enterprise. Some of them succeeded in establishing themselves as independent smiths in the countryside and had thus by their resignation resisted the threat of being subjected to a firmer rule and had maintained their position as artisans. ${ }^{73}$

Thus, from a socially and organizationally strong position the workers could fight for what they perceived to be their rights as master artisans. This is also underlined by the fact that they, as with the charcoal-burning peasants at Leufsta, were using the boycott, not the strike, as a weapon against the patron. It was thus a form of sabotage in the sphere of circulation rather than in the labour process that was the essence of their actions.

The pattern of conflict at Jäder, however, changed during the eighteenth century. A royal decree that gave the ironmaster the directing role over the guild put an end to its independent actions. His ownership of the workshops as well as his firmer control over the market also strengthened the ironmaster's social position, while the structural alteration of the network of iron production made it more difficult for the master smiths to furnish themselves with raw materials. With the deterioration of their social position the workers' demands to be respected as artisans could not be successfully defended as a question on the agenda. Claims for a profound shift of the social organization of production were dropped and instead the workers concentrated their ambitions on improving the payment. As a rule, the reformed guild could cope with the workers' demands and became, as was the case at the forge court, an arena of negotiations between workers and employer. In 1737 the last outburst of workers' open resistance occurred at Jäders Bruk, and the master smiths, allied with their journeymen, for the first time used the strike-weapon against the patron. The occurrence emphasizes the relation

${ }_{73}$ Disciplinering och konflikt, pp. 205-209.

${ }^{73}$ Ibid., p. 104. 
between the means of struggle and the social position of the producers. As they had lost their ownership of the means of production and much of their influence on the market, they chose the proletarian weapon of the strike. ${ }^{74}$

\section{WALLOONIA}

In Walloonia the peasants lacked influence at a national, parliamentary level. The political disintegration in the area, however, made the local and regional institutions more important, and at these levels there existed vast possibilities of influence. During the second half of the eighteenth century, conflicts between separate village communities and the ironworks, over the rights to forests, were fierce in many regions. It was not predominantly the price of charcoal that was disputed but the right of the ironmasters to use the woodlands of the rural communities. ${ }^{75}$ As part of the village community, the charcoal burners as well as the skilled workers in the furnaces and forges probably took part in these conflicts. It is not, however, realistic to assert that they were able to use the collective organization of the village community to put forward their own group-specific demands. A further complication seems to have been that the social multiformity in these villages also somewhat weakened the influence of the community. In Habay-la-Neuve in southern Luxemburg, a region from the seventeenth century onwards stigmatized by its large-scale iron industry, it was for example pleaded that the customary meetings of the inhabitants were hard to maintain as a consequence of the social complexity of the community with its diverse rhythms of work and leisure. ${ }^{76}$

However, hypothetically the integration of the workers in the village community could be perceived as having a variety of negative effects for the ironmaster's ambition to maintain his hegemonic position perhaps mainly by encouraging the workers to think of themselves as peasants rather then industrial workers. Some of the seasonal stops at the forges or furnaces were, for example, primarily due, not to a lack

7 Ibid:, pp. 180-183.

75 Pirotte, La terre de Durby, pp. 195-215; M. Dorban, "Trois siècles de consommation forestière dans le duché de Luxembourg 1500-1830", in D. Woronoff (ed.), Révolution et Espace Forestiers (Paris, 1987), pp. 110-112. The same sort of conflicts were evident in the iron districts in France and was further complicated by the competition between the ironworks and the urban centres, notably Paris. Paris was, unlike the urban centres in Holland and the northern part of the Netherlands, unwilling to change its fuel technology from wood to coal. J. Bossiére, "La consommation parisienne de bois et les sidérurgies périphériques: essai de mise en parallèle (milieu XVe-milieu XIXe siècles)", in Woronoff, Forges et Forets, p. 29. Complaints over the ironmasters' acquisition of wood and charcoal also was a common theme in the cahiers de doleance during the French Revolution. A. Brosselin et al., "Les doléances contre l'industrie", in Woronoff, Forges et Forets, p. 11. ${ }^{76}$ Piret, "Fortunes et Groupes Sociaux", p. 150. 
of water or raw materials, but to the necessity for agricultural work. ${ }^{n}$ The semi-agrarian identity of the industrial workforce, is also noticeable in other ways. The forgemen who worked at the nearby forges of $L a$ Trapperie, in the province of Luxemburg, were, for example, during the latter part of the eighteenth century very active on the land market in the village of Habay-La-Veille. According to the parish registers, some of them also changed their professional identity from master forgemen to farmers. ${ }^{78}$ Maybe this occurrence was not merely an outcome of the vicar's play with words and titles but also a token of the aspiration of the early industrial workers to secure their maintenance, especially as the epoch was one of diminishing returns for the local iron industry. ${ }^{79}$

Probably it was also more difficult to discipline the workers and stop them from embezzlement and illicit trade when they did not live in the immediate surroundings of the ironworks. In the village communities buyers of the goods must have been easy to find among nailers or blacksmiths. However wide the potential, problems of embezzlement are not, with a few exceptions, mentioned in the existing literature on the Walloon industry. ${ }^{80}$ Naturally it is difficult to interpret this silence on the matter as a factual non-existence of this kind of fraud. If, however, it corresponds to the real situation it is possibly a result of the differences between the German and Walloon methods of refining the pig iron. Even if it is well known that the French ironmasters complained of the workers' thefts, ${ }^{81}$ it is probable that the technical division of work in Walloon forges imposed a certain type of autocontrol. The crews at the finery hearth as well as at the chafery had to agree on and redistribute the items that had been embezzled. If not, either of them would experience a fall in income as a consequence of the diminished production. ${ }^{82}$

\footnotetext{
${ }^{n}$ Hansotte, La métallurgie, p. 71.
}

${ }^{78}$ M. Dorban, "Le dénombrement du Luxembourg en 1766 . Essai critique historique et statistique: le cas du décanat d'Yvoix-Carignan", Pays Gaumais (1971-1972), p. 62. That master forgemen were active on the market for land is also apparent in Sweden. J. Backlund, Rusthdillarna i Felingsbro 1684-1748, Indelningsverket och den sociala differentieringen av det svenska agrarsamhället (Uppsala, 1993), p. 157.

"Dorban, "La sidérurgie Luxembourgeoise", pp. 31-32.

${ }^{80}$ The exception being the problem that Abbot Nicolas Spirlet had with the workers at his furnace, forge and foundry in St Hubert. Evrard, Dom Nicolas Spirlet, p. 29.

'Woronoff, L'industrie siderurgique, p. 192.

Maybe this problem could have been solved by the workers' constituting family groups inside the factory organization. Sons often followed their fathers' choice of profession, thus, as in Sweden, creating a sort of hereditary aristocracy of skilled workers at the ironworks (Piret, "Fortunes et Groupes Sociaux", p. 206; Leboutte, La Grosse Forge Wallonne, p. 50). As the Swedish historian Goran Ryden has clearly shown, the household of the master forgeman was the basic element for establishing the work crew in the Swedish forge (Rydén, "Iron Production and the Household", pp. 18-23). Denis Woronoff has discussed the same type of phenomena in late eighteenth-century France. The influence of the workers' household over the composition of the crews, he underlines, sharply 
The role of the mining courts, notably the Cours de Ferons, is rather obscure. Since it also comprised the ironmasters, it is improbable that the workers could have used it as a weapon against their employers, but it could have had other tasks to fulfil, for example, the traditional objective of the artisan guilds to protect the honour and exclusiveness of its members. The killing of a forgeman from the Liège territory, who worked at a forge in Namur in 1769, becomes interesting in this context. Even if the crime was not ignored by the Cours de Ferons, it reveals a corporate mentality of keeping the trade free from unorganized foreigners. ${ }^{83}$ The policy had parallels in other regions during this period, in France as well as in the textile trades of the Verviers region, where the workers' organizations tried to hinder the patrons from employing foreigners. ${ }^{84}$

Illicit trade as well as embezzlement and thefts, if not mentioned in the heavy parts of the industry, however, were flourishing in the nail trade in the districts of Liège and Charleroi. It was here further complicated because of the involvement of middlemen. In Liège the marchote embezzled the raw materials as well as withholding the nailers' wages and marketing the nails. ${ }^{85} \mathrm{He}$ thus both interfered with the merchant's relation to the worker and threatened the worker's position on the market.

The tensions of the trade led to outbursts of fierce conflict during the beginning of the eighteenth century. In the countryside round Liège corporate organizations were built up by the peasant-artisans primarily to defend themselves against the wage-lowering policy of the merchants. They also strived to improve their social security as well as create what was seen as a fairer distribution of the merchant-capitalists' orders among the producers. An ambition, it seems, similar to the policy of the traditional artisan guild of distributing raw materials, journeymen and shares of the commodity market in a way that secured the survival of each incorporated household. ${ }^{86}$

The corporation was rather open and assembled both nailsmiths and workers in the slitting mills, masters as well as journeymen. During the conflicts the guild organized boycotts against the merchants, actions that,

restricted the ironmasters' possibility to direct the employment of personnel in the workshops; the family functioned as a "véritable bureau de placements" (Woronoff, L'industrie sidérurgique, p. 161).

2 Damin, La métallurgie dans le Namurois, pp. 151-152.

* P. LeBrun, L'industrie de la laine a Verviers (Liège, 1948), p. 285. See also Soly, "Social Aspects", p. 247; C. M. Truant, "Independent and Insolent: Journeymen and Their Rites in the Old Regime Workplace", in Kaplan and Koepp, Work in France, p. 132.

\&s Hansotte, La clouterie liégeoise, p. 16.

86 D. Lindström, Skrd Stad och Stat. Stockholm, Malmö och Bergen ca 1350-1622 (Uppsala, 1991), p. 23. 
in the middle of the century, were correlated with those of the nailers in Limburg in the Austrian Netherlands, an area in which the nail merchants from Liège had important economic interests. ${ }^{87}$ The organization was officially sanctioned in 1720 and functioned throughout the eighteenth century as the workers' representative at negotiations and in conflicts with the merchants. The Belgian historian George Hansotte has explained the causes behind the collective action as follows:

comme plus tard dans les manufactures de l'âge industriel, les cloutiers liègeoise du XVIIIe siècle acquièrent, dans le contact quotidien, la conscience de leur solidarité et de leur communauté d'intérêts. ${ }^{88}$

This certainly is an important explanation of the existence of a collective consciousness although it fails to explain how this led to corporate organization and action. The existence of a corporate tradition in the rural and urban communities in the region as well as the contemporaneous conflicts between rural textile workers and merchants in the nearby region of Vervier, may be additional facts helpful to complete the puzzle. ${ }^{89}$

\section{URALS}

At the beginning of the eighteenth century the socially and religiously more tolerant situation in Siberia attracted peasants from the western part of Russia, and the migration was an important precondition for the expansion of the iron industry. As feudal bonds were also tightened in the Urals, due largely to the needs of the same industry, the result was massive escapes further east or south, primarily to the regions under Cossack rule..$^{90}$ Peasants' escapes from the mining districts is thus commonly seen as the major problem for the ironworks during the eighteenth century. In the beginning of the following century bolting from the estate was becoming more rare. Even if bolting still constituted a problem it was of a new kind: from the peasants' actual working place to their villages within the district. In this way the action can in fact be seen as a form of individual and unorganized strike. ${ }^{91}$ The conscripted peasants

"7 Hansotte, La clouterie liégeoise, p. 57.

Ibid., p. 73.

The role played by rebellious or revolutionary trends in the surrounding society seems important also in order to comprehend the workers' strikes at the late eighteenth-century French ironworks. That these workers had maintained their contacts with the surrounding rural society and that the patriarchal ironwork society did not take the form of an enclosed monad, was, following Woronoff, crucial for their capability to perceive and take part in these general political occurrences. Woronoff, L'industrie sidérurgique, p. 201.

Portal, L'Oural, pp. 46, 271.

9 V. A. Shkerin, "The Process of Adoption and Social Conflicts at the Mining and Ironworks in the Urals during the Feudal Period", unpublished paper at the second meeting on iron making in Russia and Sweden before the twentieth century, Uppsala, 
had thus not lost their contact with their home villages, which is further illuminated by their complaints of being hindered from going home to take care of their farms during harvest. ${ }^{92}$

'In the latter half of the eighteenth century peasants' protests took a rebellious form. The most well-known uprising was the Pugatiev rebellion in the 1770s. As the power of the feudal landlord and the ironmaster was often inseparable, ironworks were burned by the rebels and the peasants' freedom from their obligations to produce charcoal and undertake transportation was put forward as an important issue. ${ }^{93}$ Even if the rebellions were quelled, protests were successful in so far as they resulted in an increase in the payment of the rural workers. ${ }^{94}$ This put a certain pressure on the ironworks during the latter part of the eighteenth century to contain other expenses and to rationalize production. The real structural crises, however, came a century later, as a consequence of the abolition of serfdom. ${ }^{95}$

The social unrest in the iron-producing districts was a peasant affair in which the skilled workers did not take part. The firm patriarchal rule at the ironworks and the fact that the skilled workers were divided into small work teams (compared with the gang-work of the peasants) are important factors behind the absence of workers' protest. ${ }^{96}$ Another, and more basic circumstance, is that a precondition of the peasants' escapes as well as their rebellions was the dual economy of their house-

1992, p. 4. V. A. Shkerin, "Rebellious Crowds in Social Conflicts at the Ural Private Works in the First Half of the Nineteenth Century", in Metallurgical Works, pp. 266270.

${ }^{92}$ N. A. Minenko and I. V. Pobereznikov, "The Interaction of Industry and Agricultural Environment", unpublished paper at the third meeting on iron making in Russia and Sweden before the twentieth century, Yekaterinenburg, 1993, p. 3.

${ }^{93}$ The document is published in B. Dmytryshyn (ed.), Imperial Russia: A Source Book, 1700-1917 (Portland, 1974), p. 96. The opposition during the eighteenth century also found its expressions in popular culture. One song, for example, described the prison-like conditions at the Demidov works.

A l'usine Demidov

Le travail est pénible

Ah! oui, le travail est pénible!

Hélas! nos dos nous font mall

On nous met dans une usine, un bagne

Et on ne nous laisse pas sortir [... .]

(Quoted from Portal, L'Oural, p. 289)

2 R. Portal, "Manufactures et classes sociales en Russie au XVIIIe siècle", Revue historique (1949), p. 349.

95 R. Portal, "The Industrialisation of Russia", in The Cambridge Economic History of Europe, vol. VI-2 (Cambridge, 1978), pp. 812-814. However, Thomas Esper also points to the positive economic effects that the abolition of serfdom had for the ironworks by nullifying the costs of the patriarchal cares. Esper, "The Incomes of Russian Serf Ironworkers", p. 156.

${ }^{96}$ Portal, L'Oural, pp. 294-295. 
holds, working both the land and in industry, making it possible for them to survive, or even to be better off, without the income from the ironworks. The workers at the furnaces and forges were, in this respect, in a different situation as they were dependent on industrial work.

\section{CONCLUSIONS}

The technique of large-scale iron production was roughly similar in all parts of. Europe during the early modern period. The wide spectrum of modes of social organization, therefore, must be explained by dissimilarities other than those technical. The centralized establishments in the Urals were, for example, closely connected to the major role played by the state and its possibilities, by force, to allocate the needed resources, not least labour. The industry was characterized by social homogeneity as on feudal estates a considerable proportion of the workers were unfree serfs. ${ }^{97}$

Contrary to the Uralian case, in Bergslagen and in Walloonia we find a geographically dispersed industry. The Swedish peasants maintained a strong position over mining as well as over pig iron production, during the seventeenth and most of the eighteenth centuries. Such a social distribution of the activities of furnacing and forging as was present in Sweden, never existed in Russia or in Walloonia.

In Walloonia the bourgeoisie elements in the industry were more important. Furnaces and forges during the sixteenth century were often commonly owned by merchants and skilled workers, a situation that changed during the following century when the property relations were transformed to a more classic capitalist form. The peasant workers, despite being integrated in the traditional rural communities, together with the crews from the forges and furnaces, specialized in and obtained their main income by selling products and services to the ironworks. The organization of production was, as in Russia, more homogeneous, but dominated by market relations. During the early modern period the industry witnessed social unrests and conflicts in all three regions. Overt conflicts first and foremost seem to have occurred in the, so to say, more peripheral parts of the chain of production, i.e. among charcoalers and transporters as well as among nailers and artisans at the ironmanufactures. The core of the industry, the forges and furnaces, were to a high degree free of this type of trouble. This implies that problems were most acute in the sectors closest to the peasant and traditional artisan world, sectors where the household normally was the unit of production. The integration of the households in a more rational, i.e. goal-oriented, economic organization, can hypothetically be considered as one of the main problems for the industry.

\footnotetext{
"7 For a similar development in Bohemia see Myska, "Pre-industrial Iron Making", p..53.
} 
The historian Stuart Wolf has recently underlined the need to discuss the households' choice of survival strategies in order to understand correctly the dynamics of pre-industrial economies: ${ }^{98} \mathrm{It}$ is, for example, rather obvious that, when subsumed under a more complex economic organization, such as a putting-out industry or at an ironworks, the household's strategies of maintenance could create tensions and conflicts. In their study of coal mining in the parish of Whickham in England, David Levine and Keith Wrightson demonstrate that when the surrounding households of copyholders could no longer profit from the presence of the coal mine, and when its existence instead began to challenge their agrarian livelihood, their positive attitudes turned to resistance and conflict.99

The German historian Peter Kriedte saw this type of conflict as a central component of what he called the de-industrialization process. ${ }^{100}$ In this way Kriedte together with, among others, Hans Medick and more recently Adrian Randall, has underlined the economic and cultural limits of the process of industrialization in the countryside, a process that was based on peasant households of which the primary ambition was to remain peasants. Consequently they first and foremost tried to expand their landed property and, in the long run, to find sources for their subsistence other than semi-proletarian work. ${ }^{101}$

Kriedte's thesis seems adequate to explain many of the problems that, in particular, met the Swedish and Russian ironmasters in relation to the agrarian part of the labour force. In the Urals peasants' withdrawal, due to their status as serfs, often meant escape, while in Sweden it was possible to free oneself from dependence on industrial work by developing one's own agriculture. The latter option was probably also open to the miners, charcoal burners and transporters in Walloonia, but their semi-proletarian base gave them a less favourable start and thus narrowed the scope of

${ }^{98}$ S. Woolf, "Introduction", in S. Woolf (ed.), Domestic Strategies: Work and Family in France and Italy 1600-1800 (Cambridge, 1991), p. 10.

${ }^{99} \mathrm{D}$. Levine and $\mathrm{K}$. Wrightson, The Making of an Industrial Society, Whickham 1560 1765 (Oxford, 1991), p. 110.

${ }^{100}$ P. Kriedte, "Proto-industrialization between Industrialization and De-industrialization", in P. Kriedte, H. Medick and J. Schlumbohm, Industrialization before Industrialization (Cambridge, 1981), p. 136. Or perhaps rather with D. C. Coleman's quite ironical reformulation of the concept, the deproto-industrialization. D. C. Coleman, "Protoindustrialization: A Concept Too Many", Journal of Economic History, 36 (1976), p. 443. ${ }^{101}$ H. Medick, "The Proto-industrial Family Economy: The Structural Function of Household and Family during the Transition from Peasant Society to Industrial Capitalism", Social History, 1 (1976). A. Randall, Before the Luddites (Cambridge, 1991), ch. 1. The Belgian historian Paul Servais has, in accordance with this discussion, found that the proto-industrialized textile workers in the Verviers-Liège area used their cash income to defend or expand their landed property. When the industry was centralized during the nineteenth century this strategy failed and as a result a large part of the landed property was transferred to the urban bourgeoisie. P. Servais, "Les structures agraires du Limbourg et du pays d'outre Meuse du XVIIe au XIXe siècle", Annales E.S.C., 37 (1982). 
choice of the household. Such a household strategy was not, however, restricted to the "peasant" shares of the industry. Forgemen in all three regions owned allotments of land as a supplement to their wages. Especially in Walloonia they were also active on the market for land, which can be interpreted as an outcome of a withdrawal strategy from industrial work. To deal with these groups the theoretical perspective, however, ought to be widened. To merge with the peasant group was not the only realistic alternative to change one's social position: another way was to defend or strengthen one's position as an artisan. The strong and rather independent position of the forgemen at the shop floor level and on the market facilitated different forms of everyday resistance such as embezzlement and illicit trade. From a comparative perspective, it is possible that, due to the lack of supervision and technical division of work, this type of action was more current in Sweden than in the other regions. Counterbalanced to their strong position in the workshop the Swedish workers, however, seem to have been more firmly bound in a patriarchal relationship to the ironmaster than their Walloon counterparts, who were independently integrated in the rural communities and sometimes even titled burghers. Blacksmiths and workers in the manufacturing branches of the industry, however, in this respect seem to have been even better off than the workers at the furnaces or forges. Their situation at work was close to that of a master artisan and the commodities that they produced could be sold directly on the consumer market. It also happened that the workers were organized in traditional guilds.

The wish of an individual household to maintain or strengthen its position as a farmer or artisan household highlights the motives behind the everyday resistance and also the ideology underlying the manifested demands. However, other components as well seem to be needed to explain the overt and collective conflicts. Of course the small size of the labour force was an important factor. The number of workers in forges and furnaces was relatively small when compared, for example, with peasant charcoal burners, miners or nailers. To explain the outbreak of manifest conflicts is, however, never a mere question of number. Crucial for the explanation is the workers' opportunities to communicate and organize their protests. David Levine and Keith Wrightson found that when the individual peasant protests in the coal mining society of Whickham were transformed to overt and collective conflicts at the beginning of the seventeenth century, they were based on traditional values and organization of the rural community. ${ }^{102}$ Adrian Randall argues in the same way in his study of labour conflicts in the late eighteenthcentury English textile industry. He underlines the traditions and organizations of craftsmanship and the artisan independence as important factors behind the revolt of the workers. ${ }^{103}$

102 Levine and Wrightson, The Making of an Industrial Society, pp. 118-120.

${ }^{103}$ Randall, Before the Luddites, p. 33. See also LeBrun, L'industrie de la laine, p. 268. 
In Sweden, as in Walloonia, traditional channels of influence existed for the peasants' protest on a regional and, in the former country, even on a national and political level. It is, however, probable that the possibility for the Walloonian workers to use these channels for their specific claims was rather limited, as a consequence of their semiproletarian status. In the Urals the conscripted peasants worked collectively and had preserved their links to the village community, factors which created a solid ground for collective action. As political channels for peasant influence were non-existent, the protests, contrary to the situation in the other two regions, took a rebellious character.

In the forges and furnaces the artisan-like position of the worker corresponded to the construction of guild-like corporations in Sweden as well as in some areas of Walloonia. As a consequence of the lack of guild traditions in the surrounding community and the inclusion of the industry in the feudal estate, such organizations were never established in the Urals. ${ }^{104}$

The corporations that were built up for the forgemen resulted in conflicts being institutionalized, though not by masters freely using them in their own interest against the ironmasters. In the manufacturing branch of the industry, however, traditional forms of guilds existed that functioned as representatives for the workers. In the cases referred to in Sweden these were transformed and disarmed during the eighteenth century. In Liège, on the other hand, the conflicts between nailers and merchants, despite the decentralized structure of the industry, gave birth to new guild-like organizations for the workers.

The economy of the household, and also the workers' artisan-like position, made it possible for them to use ideologies and put up demands that, although being the result of a historically new position, could be articulated in the corporate language of the old society and communicated through their traditional organizations. To make such a use of the old discourse, however, had its limits. ${ }^{105}$ The development at Jäders Bruk shows that resistance was most stern and far-reaching when the workers could pose their demands from an artisan's position and make use of their guild organization. When their social position was eroded and their organization usurped by the patron, the protests and demands took more conciliatory forms.

The existence of discord does not automatically cause overt and collective struggle. Nor is it a question of in which link of the chain of production oppression is seen as being hardest. Organized protest can

${ }^{10 s}$ Portal, L'Oural, p. 19; M. Raeff, The Well-ordered Police State. Social and Institutional Change through Law in the Germanies and Russia, 1600-1800 (New Haven, 1983), p. 213. ${ }^{\text {tos }}$ David Levine and Keith Wrightson have demonstrated that when the class of copyholders in Whickham socially and economically became more diversified, the resistance against the coal mine withered away. Levine and Wrightson, The Making of an Industrial Society, p. 138. 
of course be a desperate action against the oppressor, but is more often a conscious choice between different options. Choosing open conflict then reveals that the workers perceived themselves as being in a socioeconomically, as well as organizationally and ideologically, strong position. Such a position is evident for the peasant-workers as well as for the workers in the artisan-like trades of the iron industry, where the household had preserved a more independent position and, therefore, the alternative of being a "real" farmer or "artisan" was still a live reality. In these sectors traditional values and organizations could also be used in order to take up the struggle.

The social organization of the European iron industry before the Industrial Revolution was multiform. It varied between separate regions as well as between the different stages in the chain of production in the same region. Causes of conflict, but also the strategies and means of organizations that were open for the workers' choice in that conflict, were dependent on the social organization of production as well as on its wider societal context. The Industrial Revolution meant a homogenization of techniques as well as of social relations. Conflicts and workers' organizations existed and played a vital role for the development of the proto-industrial iron industry, although they were not, however, as stereotyped as they are in modern society. A search for types of conflicts or organizations as dominant as the modern strike and trade union is, by definition, a search in vain. 